\title{
Frameless
}

Volume 1 | Issue 1

Article 17

November 2019

\section{Mixed Reality Ideation}

Ralf O. Schneider
Syracuse University, rosch100@syr.edu

Follow this and additional works at: https://scholarworks.rit.edu/frameless

\section{Recommended Citation}

Schneider, Ralf O. (2019) "Mixed Reality Ideation," Frameless: Vol. 1: Iss. 1, Article 17.

DOI: 10.14448/Frameless.01.004

Available at: https://scholarworks.rit.edu/frameless/vol1/iss1/17

This Research Abstract is brought to you for free and open access by RIT Scholar Works. It has been accepted for inclusion in Frameless by an authorized editor of RIT Scholar Works. For more information, please contact ritscholarworks@rit.edu. 


\title{
FRAMEEESS
}

\section{Mixed Reality Ideation}

\author{
Ralf O. Schneider \\ Industrial and Interaction Design \\ Syracuse University
}

The recent development of Mixed Reality (MR) devices and apps hint at an exciting future. To be true to the inherent innovative spirit of the design profession, it is important to expose students to MR in the classroom in an exploratory setting.

At this time, integrating MR in design education makes sense in higher-level design studio courses. As the digitally native generation enters college age, their fluid handling of digital tools will support the use of MR technology in freshman and sophomore courses. For design educators it is important to be prepared for this transition and to support students in playfully working with digital content and tools.

This project demonstrates a multistep approach to the MR ideation process. Analog or digital sketching on equirectangular templates result in the simulation of a 360-degree environment. Three-dimensional VR sketching with the programs Google Tiltbrush and Gravity Sketch enable a more detailed understanding of an idea in space. Sketchnoting as a means of storytelling and the translation of key moments into Unity in either a VR or AR setting allow for communicating the design intent at a high resolution. Iteration on all levels of this refinement process and critically assessing the merit for the end user accompanies decision making along the way.

Takeaways from MR projects conducted in an academic setting in the design program at Syracuse University will be shared. This is a design education story that exemplifies the unique value of engaging in MR design development. 